\title{
Alleviation of Cadmium Toxicity in Triticum aestivum Using the Coagulant Defatted Moringa oleifera and Moringa peregrina Seeds Powder.
}

\author{
Raifa A. Hassanein, Amal F. Abd El-kader, Heba M. \\ Faramawy* \\ Botany Department, Faculty of Science, Ain Shams University, \\ Cairo, Egypt.
}

\begin{abstract}
T HE PRESENT study explores the unexploited sorption properties of Moringa oleifera Lam (MO)and Moringa peregrina Foresk (MP) for decontamination of $\mathrm{Cd}^{2+}$ at laboratory scale. Triticum aestivum plants were grown under $\mathrm{Cd}^{2+}$ stress. Moringa seed powder (3 $\mathrm{g} / \mathrm{kg}$ soil) of both species were mixed with the soil before wheat sowing. After ten days, the Cd-concentrations were applied to the treated pots $(0.0,0.5,1.0$ and $1.5 \mathrm{mM})$. Plant samples were collected at 5 weeks post sowing to assess the growth traits and certain physiological parameters. Growth traits, relative water content, photosynthetic pigments were decreased under $\mathrm{Cd}^{2+}$ stress. However, the application of Moringa seed powder can detoxify the toxic effect of cadmium acetate stress on the above parameters. The $\mathrm{Cd}^{2+}$ stress increased the $\mathrm{Cd}^{2+}$ contents in roots and shoots of wheat plants, but in the Moringa seed powder-treated plants under $\mathrm{Cd}^{2+}$ stress revealed a reverse situation. Both Moringa species can coagulate $\mathrm{Cd}^{2+}$ from the soil by the presence of proteins having coagulation properties (MWts 64.5, 51.4, 41.2, 38.3, 27.9 and $18.9 \mathrm{KDa}$ ). The effect of MO seed powder in mitigating the adverse effect of $\mathrm{Cd}^{2+}$ stress on wheat plant was much pronounced than that of MP seed powder.
\end{abstract}

Keywords: Biodegradable, Biosorption, Moringa oleifera seed powder, Moringa peregrine seed powder, Organic fertilizer, Seed-cake.

Abbreviation: MO: Moringa oleifera, MP: Moringa pergrina, MSP: Moringa seed powder, OSP: Oleifera seed powder, PSP: Peregrina seed powder.

Wheat is a major agricultural commodity and dietary components across the world, where it is the most widely grown crop species in the world (Rezzoug et al., 2008). Wheat is one of the most important cereals in view of nutritional value (Abd El-Baky, 2009). It serves as a rich source of carbohydrates, essential amino acids, fiber components, minerals and vitamins in the human diet (Fardet et al., 2008). In Egypt, wheat is considered as the first strategic food crop. It has maintained its position as the basic staple food in urban areas, and mixed with maize in rural areas for bread making. In addition, wheat straw can be considered as an important fodder (Amin et al., 2008).

*Corresponding author; hm_botany@yahoo.com. 
Heavy metal stress leads to loss in a regular productivity and induces hazardous health effects. Heavy metals have largest availability in soil and aquatic ecosystems and to a relatively smaller proportion in atmosphere as particular or vapors. Among the toxic heavy metals, $\mathrm{Cd}^{2+}$ is a non-essential heavy metal pollutant naturally present in the environment. Cadmium containing phosphate fertilizers, sewage sludge and industrial emissions are the major sources of $\mathrm{Cd}^{2+}$ (Howlader, 2014). Cadmium and certain $\mathrm{Cd}^{2+}$ compounds are listed by International Agency for Research on Cancer (IARC) as carcinogenic agent. $\mathrm{Cd}^{2+}$ - at low levels over prologed periods- causes high blood pressure, sterility among males, kidney damage and flu disorders (Nand et al., 2012). If plants exposed to high levels of $\mathrm{Cd}^{2+}$, photosynthetic rate, water and nutrient uptake be will inhibited and finally death will occur (Agami and Mohamed, 2013).

Environmental pollution by toxic metals occurs globally through military, industrial and agricultural process and was disposal (Kumari et al., 2005), this has led to a need of means of purifying of water for various roles it plays in our lives. This can be achieved by the addition of chemical coagulants such as aluminum sulphate and synthetic electrolyte that may be toxic, to the raw water (Foidle et al., 2001). Also activated carbon is an absorbent that widely used in the treatment of contaminated water, however its use in large scale becomes costly (Babel and Kurniawan, 2003). Thus, the search for low cost and high efficiency adsorbents has led to study alternative natural absorbents such as waste agricultural and agro-industrial byproducts, which generally have the advantage of being produced in large quantities, and many of these materials have potential in sorption of metal ions and hence are known as biosorbants (Santos et al., 2011). One of these materials is the byproduct obtained from Moringa seeds which has the ability to join the heavy metals to form complex with ions in solutions (Pagnanelli et al., 2003). Due to this characteristic, Moringa becomes a very attractive option for water remediation. Moringa crushed seed powder yields water soluble proteins that can coagulate wastes from water (Foidle et al., 2001). in this respect, Ndabigengesere et al. (1995) reported that the active components in Moringa oleifera seeds are soluble cationic proteins and peptides with molecular weight ranging from 6 to $16 \mathrm{KDa}$. However, Himesh et al. (2007) reported the isolation of a high molecular mass protein $(66 \mathrm{KDa})$ having coagulation activity. The percentage removal of heavy metals from waste water by Moringa oleifera seeds was recorded $80 \%$ for $\mathrm{Pb}$ and $60 \%$ for Cd (Nand et al., 2012). The present investigation was conducted as a trial to mitigate $\mathrm{Cd}$ toxicity on wheat plant using defatted seeds powder of Moringa oleifera and Moringa peregrina plants as coagulants.

\section{Materials and Methods}

\section{Plant material preparation}

The seeds of both mature Moringa species (MO and MP) were collected from El- Kanatter Horticultural Research Station (Agricultural Research Center, Kalubia Governorate, Egypt) and El- Orman Garden (Giza), respectively. The

Egypt. J. Bot., Vol. 56, No. 3 (2016) 
seeds were then air-dried and defatted from their oil content using n-hexane through soxhlet apparatus (Meara, 1955). The seed cake resulted from extraction was left in air to evaporate the residual solvent. The seed-cake was applied (about $3 \mathrm{~g}$ for each pot) to soil-cultivated with wheat to test the activity of both Moringa sp. to coagulate $\mathrm{Cd}^{2+}$ from the Cd-contaminated soil (Foidle et al., 2001). Also, the seeds of both species were analyzed, then their chemical constituents and protein pattern, were presented in (Table 1, 2 and Plate 1).

\section{Growth conditions}

Before sowing wheat grains, every $\mathrm{Kg}$ soil was mixed with three $\mathrm{g}$ of defatted Moringa oleifera or peregrina seeds powder except for controls (pots irrigated with $\mathrm{H}_{2} \mathrm{O}, 0.5,1.0$ and $1.5 \mathrm{mM} \mathrm{Cd}$ ), then seeds of wheat (Triticum aestivum) were sown in plastic pots $(15 \mathrm{~cm}$ in diameter and $15 \mathrm{~cm}$ in depth). Each pot was filled with one $\mathrm{kg}$ soil (clay: sand; $2: 1 \mathrm{w} / \mathrm{w}$ ) and contained 5 plants. The study was conducted under natural conditions during winter. The average temperature was $21 \pm 2{ }^{\circ} \mathrm{C}$, the seedlings were irrigated with tap water and raised at $70 \%$ water holding capacity. The plants were left to grow in the greenhouse and after ten days post sowing, Cd-acetate with different concentrations $(0.5$ $\mathrm{mM}, 1.0 \mathrm{mM}$ and $1.5 \mathrm{mM}$ ) was added to the soil in treatments alone, or in combination with MO or in combination with MP in treatments. Each treatment was carried out in three replicates. Plant samples were collected at 5 weeks post sowing to assess the growth traits and certain physiological parameters (fresh leaves of plant samples were used to determine photosynthetic pigments, relative water content and $\mathrm{Cd}^{+2}$ content in leaves and roots. Protein banding pattern in fresh leaves was also determined.

\section{Plant growth analyses}

Wheat plants were removed from the pots along with the soil and were dipped in a beaker filled with water. Plants were moved smoothly to remove the adhering soil particles. Root and shoot lengths were measured by using a meter scale. The dry weights of shoots and roots were determined by placing the fresh materials in an oven run at $70{ }^{\circ} \mathrm{C}$ up to constant weight. These dried plants were weighed to record dry mass of shoots and roots (Howladar, 2014).

\section{Hormonal analysis}

The method of hormone extraction was essentially similar to that adopted by Wasfy et al. (1974). During the extraction method there are two fractions, the fraction of the ethanol extract (acidic fraction) containing the acidic hormones (IAA, GA3) and was determined with the method described by Shindy and Smith (1975) using HEWLETT PACKERED Gas Chromatography (5890) with a Flame Ionization Detector (FID). The aqueous fraction comprised cytokinins that were quantified using High Performance Liquid Chromatography (HPLC) according to the method adopted by Muller and Hilgenberg (1986).

\section{Determination of relative water content}

Relative water content (RWC) was determined in fresh leaf segments $(1 \mathrm{~cm} \mathrm{x}$ $3 \mathrm{~mm}$ ). Segments were weighed quickly and immediately placed on double 
distilled water in Petri-dishes to saturate them with water for about $24 \mathrm{hr}$ in dark. The leaf segments were reweighed to note the adhering water and turgid mass. Dry mass of the leaf segments was recorded after dehydrating them at $70{ }^{\circ} \mathrm{C}$ for $48 \mathrm{hr}$. The \% RWC was calculated using the following formula giving by Howladar (2014)

$$
\text { RWC }=\frac{\text { Fresh mass- dry mas }}{\text { Turgor mass- dry mass }} \times 100
$$

\section{Determination of photosynthetic pigments}

The photosynthetic pigments (chlorophyll a, chlorophyll $\mathrm{b}$ and carotenoids) were determined according to spectrophotometric method adopted by Metzner et al. (1965). A sample of $0.5 \mathrm{~g}$ of 35-day old fresh leaves was homogenized in $85 \%$ aqueous acetone for $5 \mathrm{~min}$. The homogenate was centrifuged. The optical densities of acetone extract were measured at 3 wave lengths of 663,644 and $452.5 \mathrm{~nm}$ using Spectronic 601 Spectrophotometer.

\section{Determination of proline contents}

Free proline was estimated according to the method described by Bates et al. (1973). Intensity of color of toluene phase was red at $520 \mathrm{~nm}$ using Spectronic 601 Spectrophotometer.

\section{Determination of carbohydrate contents}

The carbohydrates were extracted according to Prud'homme et al. (1992). The total soluble fraction was determined using modification of the procedures of Yemm and Wilis (1954). The polysaccharides were determined using Thayermanavan and Sadasivam (1984). Total carbohydrates were calculated as the sum of the amount of soluble sugars and polysaccharides.

\section{Determination of protein contents}

The total proteins (soluble and insoluble proteins) were determined by using Folin-Ciocalteu reagent according to the method described by Daughaday et al. (1952) and the total proteins were calculated as the sum of the amount of soluble and insoluble proteins.

\section{Determination of amino acids and total nitrogen contents}

Amino acids extracted by using the method adopted by Hassanein (1977). Free amino acids were directly determined in the extract according to Muting and Kaiser (1963). Total-N was determined by the conventional micro-kjeldahl method.

\section{Determination of ascorbate and glutathione contents}

The method used for estimation of ascorbic acid (ASA) was described by Barakat et al. (1973). The reduced glutathione was determined by using the method adopted by Hissin and Hilf (1976). 


\section{Determination of total phenols and flavonoids}

Total phenols were extracted by the method of Danial and George (1972) and measured at $725 \mathrm{~nm}$ using Spectronic, 601. Whereas, the flavonoids extracts were prepared using the modified method of Malkowski and piotrowska (2006). The intensity of pink color of flavonoid samples was measured at $510 \mathrm{~nm}$ using Spectoronic 601 .

\section{Determination of certain elements}

Elements extracted according to Chapman and Pratt (1961). Potassium elements was estimated by the Flame Photometer Emission Technique as described by Ranganna (1977). Calcium, magnesium, iron, manganese, phosphorus and cadmium were determined simultaneously by inductively coupling plasma (ICP) spectroscopy according to the method of Saltanapour (1985) and calculated as $\mathrm{mg} / 100 \mathrm{~g} \mathrm{DW}$

\section{Determination of fibers content}

Jenkins method (1930) was used to determine cellulose content. The method used for pectin content was that adopted by Nanji and Norman (1928).

\section{Determination of oil content}

Oils were extracted as described by Meara (1955). Extraction made with petroleum ether in a soxhlet apparatus and continued for 18 hours.

protein banding pattern

The method used in analyzing the protein banding pattern of soluble protein was carried out according to the method described by Hames and Ricwood (1981).

\section{Statistical Analysis}

Data were analyzed by a simple variance analysis (ANOVA) using program SPSS17.

\section{Results}

Biochemical composition of seeds of $M O$ and $M P$

MO and MP seeds were analyzed and their chemical constituents were presented in (Table 1). As shown from the table, the seeds of the two Moringa species contained considerable amounts of phytohormones namely IAA, $\mathrm{GA}_{3}$, zeatin, zeatin riboside and benzyl adenine. With regard to primary metabolites, namely total carbohydrates, total proteins and total lipids; they are higher in MO compared with MP. Concerning the mineral elements, both Moringa species contained higher levels of $\mathrm{Ca}, \mathrm{K}, \mathrm{P}$ and $\mathrm{Mg}$, but minute amounts of $\mathrm{Mn}$ and $\mathrm{Fe}$.

In addition, MO and MP seeds are rich in antioxidant compounds such as ascorbic acid, reduced glutathione, total flavonoids and total phenols. 
TABLE 1. Biochemical composition of fully matured seeds of Moringa oleifera and Moringa peregrina plants.

\begin{tabular}{|c|c|c|c|}
\hline $\begin{array}{c}\text { Chemical } \\
\text { Compounds }\end{array}$ & & M. oleifera seed & M.peregrina seed \\
\hline \multirow{5}{*}{$\begin{array}{l}\text { Phytohormones } \\
(\mu \mathrm{g} / \mathrm{g} D W)\end{array}$} & Auxin (IAA) & $91.16 \pm 3.242$ & $143.50 \pm 4.912$ \\
\hline & GA3 & $186.77 \pm 6.110$ & $247.17 \pm 4.900$ \\
\hline & Zeatin & $6088.33 \pm 136.961$ & $4070.20 \pm 180.639$ \\
\hline & Zeatin riboside & $25.78 \pm 4.595$ & $63.10 \pm 10.523$ \\
\hline & Benzyl adinine & $455.83 \pm 25.750$ & $344.20 \pm 15.235$ \\
\hline \multirow{3}{*}{$\begin{array}{l}\text { Carbohydrates } \\
(\mathrm{g} / 100 \mathrm{~g} \text { DW) }\end{array}$} & $\begin{array}{c}\text { Total soluble Sugars } \\
\text { (TSS) }\end{array}$ & $3.77 \pm 0.221$ & $2.16 \pm 0.208$ \\
\hline & Poly saccarides & $5.61 \pm 1.013$ & $2.26 \pm 0.354$ \\
\hline & Total carbohydrates & $9.38 \pm 1.276$ & $4.42 \pm 0.148$ \\
\hline \multirow{6}{*}{$\begin{array}{l}\text { Nitrogenous } \\
\text { compounds } \\
(\mathrm{g} / 100 \mathrm{~g} \mathrm{DW})\end{array}$} & Soluble proteins & $11.25 \pm 0.107$ & $6.61 \pm 0.023$ \\
\hline & Insoluble proteins & $3.42 \pm 0.312$ & $2.70 \pm 0.033$ \\
\hline & Total proteins & $14.67 \pm 0.219$ & $9.3 \pm 0.010$ \\
\hline & Total nitrogen & $29.14 \pm 3.732$ & $16.11 \pm 1.609$ \\
\hline & Amio nitrogen & $0.17 \pm 0.017$ & $0.12 \pm 0.008$ \\
\hline & Proline & $0.01 \pm 0.001$ & $0.01 \pm 0.000$ \\
\hline \multicolumn{2}{|c|}{ Total lipids (\%) } & $32.71 \pm 4.503$ & $25.53 \pm 1.861$ \\
\hline \multirow{6}{*}{$\begin{array}{l}\text { Minerals } \\
(\mathrm{mg} / 100 \mathrm{~g} \text { DW) }\end{array}$} & $\mathrm{Mn}^{2+}$ & $0.73 \pm 0.085$ & $0.49 \pm 0.032$ \\
\hline & $\mathrm{Fe}^{3+}$ & $2.84 \pm 0.268$ & $5.38 \pm 1.295$ \\
\hline & $\mathrm{Ca}^{2+}$ & $333.17 \pm 7.281$ & $171.17 \pm 5.901$ \\
\hline & $\mathrm{K}^{+}$ & $733.51 \pm 6.500$ & $338.83 \pm 6.001$ \\
\hline & $\mathrm{P}^{3+}$ & $415.91 \pm 4.556$ & $272.67 \pm 11.504$ \\
\hline & $\mathrm{Mg}^{2+}$ & $90.84 \pm 7.780$ & $110.67 \pm 11.676$ \\
\hline \multicolumn{2}{|c|}{ Fibers (g/100 g DW) } & $49.82 \pm 0.351$ & $48.28 \pm 0.300$ \\
\hline \multicolumn{2}{|c|}{ Ascorbic acid (mg/100g DW) } & $100.60 \pm 7.006$ & $56.54 \pm 0.676$ \\
\hline \multicolumn{2}{|c|}{ Reduced glutathione (mg/100g DW) } & $2139.23 \pm 194.45$ & $3696.30 \pm 583.35$ \\
\hline \multicolumn{2}{|c|}{ Total flavonoids (mg/100g DW) } & $0.16 \pm 0.013$ & $0.33 \pm 0.025$ \\
\hline \multicolumn{2}{|c|}{ Total phenols (mg/100g DW) } & $1316.19 \pm 39.942$ & $403.21 \pm 10.261$ \\
\hline
\end{tabular}

Protein banding pattern of seeds of MO or MP

Seeds of MO are characterized by the presence of 5 polypeptides, their molecular weights are 87.82, 73.0, 58.7, 46.23, and 23.3 KDa. However, seeds of MP are characterized by the presence of 4 protein bands, their molecular weights are 115.4, 97.0, 53.9 and 36.50 KDa (Table 2 and plate 1). The two Moringa species are characterized by the presence of 6 protein bands, their molecular weights are 64.5, 51.4, 41.2, 38.3, 27.9 and 18.9 KDa (Table 2 and plate 1). 
TABLE 2. Protein banding pattern of Moringa oleifera and Moringa peregrina seeds (molecular weight; MWt and amounts).

\begin{tabular}{|c|c|c|c|c|c|}
\hline \multirow{2}{*}{$\begin{array}{l}\text { MW } \\
\text { KDa } \\
\end{array}$} & \multicolumn{2}{|c|}{ Moringa oleifera seeds } & \multicolumn{2}{|c|}{ Moringa peregrina seeds } & \multirow{2}{*}{$\begin{array}{l}\text { MW } \\
\text { MW }\end{array}$} \\
\hline & MW & amount & MW & amount & \\
\hline 116 & $\begin{array}{ll}---- \\
\end{array}$ & ---- & $\begin{array}{ll}---- \\
\end{array}$ & ----- & 116 \\
\hline 115.44 & $\begin{array}{ll}---- \\
-\end{array}$ & $\begin{array}{ll}---- \\
--\end{array}$ & 115.4 & 1.85 & $\begin{array}{ll}---- \\
--1\end{array}$ \\
\hline 100.40 & $\begin{array}{ll}---- \\
--\end{array}$ & $\begin{array}{ll}---- \\
--\end{array}$ & ----- & $\begin{array}{ll}---- \\
--\end{array}$ & $\begin{array}{cc}---- \\
\end{array}$ \\
\hline 98.70 & +---- & +---- & +---- & ----- & ---- \\
\hline 97.0 & ----- & ----- & 97.0 & 1.94 & 97 \\
\hline 94.7 & ----- & ----- & ----- & ----- & ---- \\
\hline 91.3 & $\begin{array}{ll}---- \\
\end{array}$ & $\begin{array}{ll}---- \\
\end{array}$ & $\begin{array}{ll}---- \\
\end{array}$ & $\begin{array}{ll}---- \\
\end{array}$ & $\begin{array}{c}---- \\
\end{array}$ \\
\hline 87.82 & 87.82 & 3.87 & ----- & ----- & ---- \\
\hline 84.40 & ----- & ----- & ----- & ----- & $\begin{array}{c}---- \\
--1\end{array}$ \\
\hline 79.8 & ----- & ----- & ----- & $\begin{array}{ll}---- \\
\end{array}$ & ----- \\
\hline 75.8 & $\begin{array}{ll}---- \\
--\end{array}$ & 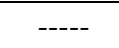 & $\begin{array}{ll}---- \\
--1\end{array}$ & $\begin{array}{ll}---- \\
--\end{array}$ & $\begin{array}{ll}---- \\
\end{array}$ \\
\hline 73.0 & 73.0 & 2.75 & $\begin{array}{ll}---- \\
\end{array}$ & $\begin{array}{ll}---- \\
\end{array}$ & $\begin{array}{ll}---- \\
\end{array}$ \\
\hline 66.0 & ----- & ----- & ----- & ----- & 66 \\
\hline 64.5 & 64.5 & 3.97 & 64.5 & 4.97 & ----- \\
\hline 58.7 & 58.7 & 2.13 & ----- & ----- & ----- \\
\hline 55.0 & ----- & ----- & ----- & ----- & 55 \\
\hline 53.9 & ----- & ----- & 53.9 & 5.31 & \\
\hline 51.4 & 51.4 & 7.55 & 51.4 & 9.46 & ----- \\
\hline 46.23 & 46.23 & 5.11 & ----- & ----- & ---- \\
\hline 45.0 & ----- & $\begin{array}{l}---- \\
--\end{array}$ & ----- & $\begin{array}{l}---- \\
-\end{array}$ & 45 \\
\hline 41.20 & 41.20 & 5.08 & 41.20 & 3.92 & $\begin{array}{l}---- \\
\end{array}$ \\
\hline 38.30 & 38.30 & 4.07 & 38.30 & 3.21 & ---- \\
\hline 36.50 & ----- & ----- & 36.50 & 4.59 & ---- \\
\hline 36 & ----- & ----- & ----- & ----- & 36 \\
\hline 29.0 & ----- & ----- & ----- & ----- & 29 \\
\hline 27.9 & 27.9 & 8.55 & 27.9 & 8.7 & ---- \\
\hline 26.0 & ----- & ----- & ----- & ----- & ----- \\
\hline 24.0 & ----- & ----- & ----- & ----- & 24 \\
\hline 23.3 & 23.3 & 3.67 & ----- & ----- & ----- \\
\hline 18.9 & 18.9 & 4.10 & 18.9 & 4.25 & ---- \\
\hline 15.5 & ----- & ----- & ----- & ----- & ---- \\
\hline 14.2 & ----- & ----- & ----- & ----- & 14.2 \\
\hline 12.2 & ----- & $\begin{array}{l}---- \\
--\end{array}$ & $\begin{array}{l}---- \\
--\end{array}$ & $\begin{array}{l}---- \\
\end{array}$ & ----- \\
\hline $\begin{array}{c}\text { Number of } \\
\text { bands }\end{array}$ & 11 & ----- & 10 & ----- & ----- \\
\hline
\end{tabular}




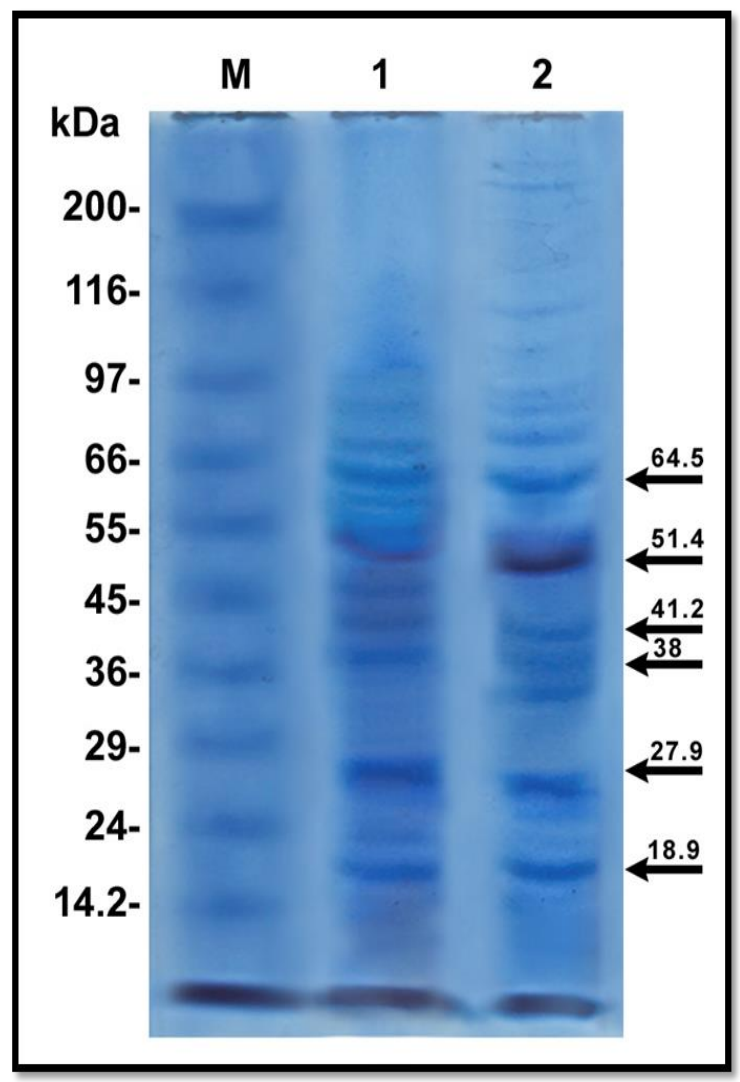

Plate 1. Electrograph of soluble protein pattern by one dimension SDS-PAGE showing the proteins presented in the seeds of Moringa oleifera and Moringa peregrina.

Lane(1): Moringa oleifera.

Lane(2): Moringa peregrina.

Effect of seed powder of MO or MP on wheat growth under $\mathrm{Cd}^{2+}$ stress

Cadmium application significantly reduced the growth traits (lengths of shoot and root, fresh and dry weights of root and shoot) of wheat plant, especially at the highest concentration $(1.5 \mathrm{mM})$ compared to control plants. It had been found that soil application with Moringa seed powder of the two species separately, significantly increased the above mentioned growth traits higher than the control plants, especially in the case of MO. Application of Moringa seed powder of the two species in combination with different concentration of $\mathrm{Cd}^{2+}$ significantly increased the previous growth traits of wheat plants compared with their relative treated controls. Generally, the seed powder of both species (either separately or combined with $\mathrm{Cd}^{2+}$ ) significantly increased both fresh and dry weights of root of wheat plant with the superiority of MO seed powder compared to that of MP seed powder (Table 3).

Egypt. J. Bot., Vol. 56, No. 3 (2016) 
TABLE 3. Effect of soil application of defatted Moringa oleifera (OS) and Moringa peregrina (PS) seeds on growth parameter of 35 day old seedlings of wheat (Triticum aestivum) grown under Cd-acetate stress. Each value is the mean of three variables.

\begin{tabular}{|c|c|c|c|c|c|c|}
\hline Parameters & $\begin{array}{c}\text { Length } \\
\text { of Shoot } \\
\text { (cm) }\end{array}$ & $\begin{array}{c}\text { Shoot } \\
\text { FW }\end{array}$ & $\begin{array}{c}\text { Shoot } \\
\text { DW }\end{array}$ & $\begin{array}{c}\text { Length } \\
\text { of Root } \\
(\mathrm{cm})\end{array}$ & $\begin{array}{l}\text { Root } \\
\text { FW }\end{array}$ & $\begin{array}{l}\text { Root } \\
\text { DW }\end{array}$ \\
\hline Control & $\begin{array}{c}25.82 \\
\pm 0.27^{\mathrm{b}}\end{array}$ & $\begin{array}{c}334.03 \pm \\
9.35^{\mathrm{b}}\end{array}$ & $\begin{array}{c}30.15 \pm \\
0.76^{\mathrm{c}}\end{array}$ & $\begin{array}{l}11.22 \pm \\
0.22 \mathrm{bc}\end{array}$ & $\begin{array}{c}41.28 \pm \\
1.26^{\mathrm{c}}\end{array}$ & $\begin{array}{l}8.14 \pm \\
0.51^{\mathrm{cd}}\end{array}$ \\
\hline MO & $\begin{array}{c}27.64 \pm \\
0.21^{\mathrm{a}}\end{array}$ & $\begin{array}{c}350.14 \pm \\
9.36^{\mathrm{a}}\end{array}$ & $\begin{array}{c}34.88 \pm \\
1.80^{\mathrm{a}}\end{array}$ & $\begin{array}{l}12.44 \pm \\
0.41^{\mathrm{a}}\end{array}$ & $\begin{array}{l}55.02 \pm \\
1.81^{\mathrm{a}}\end{array}$ & $\begin{array}{l}9.39 \pm \\
0.41^{\mathrm{a}}\end{array}$ \\
\hline MP & $\begin{array}{c}26.29 \pm \\
0.22^{\mathrm{b}}\end{array}$ & $\begin{array}{c}342.58 \pm \\
3.13^{\mathrm{ab}}\end{array}$ & $\begin{array}{c}31.39 \pm \\
0.86^{\mathrm{b}}\end{array}$ & $\begin{array}{l}11.79 \pm \\
0.31^{\mathrm{b}}\end{array}$ & $\begin{array}{l}44.52 \pm \\
1.62^{\mathrm{b}}\end{array}$ & $\begin{array}{l}8.95 \pm \\
0.37^{\mathrm{ab}}\end{array}$ \\
\hline $\mathrm{Cd}(0.5 \mathrm{mM})$ & $\begin{array}{r}24.64 \pm \\
0.42^{\mathrm{c}}\end{array}$ & $\begin{array}{c}242.68 \pm \\
1.71 \mathrm{de}\end{array}$ & $\begin{array}{l}26.92 \pm \\
0.41 \mathrm{e}^{\mathrm{e}}\end{array}$ & $\begin{array}{l}9.89 \pm \\
0.61^{\mathrm{e}}\end{array}$ & $\begin{array}{c}33.95 \pm \\
0.56^{\mathrm{fg}}\end{array}$ & $\begin{array}{l}7.21 \pm \\
0.30 \text { ef }\end{array}$ \\
\hline Cd (1.0 mM) & $\begin{array}{r}21.92 \pm \\
0.46^{\mathrm{g}}\end{array}$ & $\begin{array}{c}182.95 \pm \\
5.37^{\mathrm{g}}\end{array}$ & $\begin{array}{c}21.72 \pm \\
0.59^{\mathrm{h}}\end{array}$ & $\begin{array}{l}8.39 \pm \\
0.54^{\mathrm{gh}}\end{array}$ & $\begin{array}{r}29.73 \pm \\
0.73^{\mathrm{i}}\end{array}$ & $\begin{array}{l}6.18 \pm \\
0.30^{\mathrm{g}}\end{array}$ \\
\hline $\mathrm{Cd}(1.5 \mathrm{mM})$ & $\begin{array}{c}17.85 \pm \\
0.35^{\mathrm{h}}\end{array}$ & $\begin{array}{c}139.25 \pm \\
2.58^{\mathrm{h}}\end{array}$ & $\begin{array}{r}18.05 \pm \\
0.30^{\mathrm{j}}\end{array}$ & $\frac{6.81 \pm}{0.30}$ & $\begin{array}{l}21.28 \pm \\
0.80^{\mathrm{k}}\end{array}$ & $\begin{array}{l}5.09 \pm \\
0.46^{\mathrm{h}}\end{array}$ \\
\hline $\begin{array}{c}\mathrm{Cd} \\
(0.5 \mathrm{mM})+\mathrm{MO}\end{array}$ & $\begin{array}{l}25.61 \pm \\
0.43^{\mathrm{b}}\end{array}$ & $\begin{array}{c}303.27 \pm \\
8.58^{\mathrm{c}}\end{array}$ & $\begin{array}{r}28.53 \pm \\
0.20^{\mathrm{d}}\end{array}$ & $\begin{array}{l}10.75 \pm \\
0.36^{\text {cd }}\end{array}$ & $\begin{array}{c}37.42 \pm \\
1.05^{\mathrm{d}}\end{array}$ & $\begin{array}{l}8.35 \pm \\
0.15^{\mathrm{bc}}\end{array}$ \\
\hline $\begin{array}{c}\text { Cd }(0.5 \mathrm{mM}) \\
+\mathrm{MP}\end{array}$ & $\begin{array}{l}24.28 \pm \\
0.68^{\mathrm{cd}}\end{array}$ & $\begin{array}{l}246.62 \pm \\
3.56^{\mathrm{d}}\end{array}$ & $\begin{array}{l}27.86 \pm \\
0.30 \mathrm{de}\end{array}$ & $\begin{array}{l}10.28 \pm \\
0.21 \mathrm{de}\end{array}$ & $\begin{array}{l}35.95 \pm \\
0.66^{\mathrm{de}}\end{array}$ & $\begin{array}{l}7.58 \pm \\
0.47 \mathrm{de}\end{array}$ \\
\hline $\begin{array}{c}\text { Cd (1.0 } \\
\mathrm{mM})+\mathrm{MO}\end{array}$ & $\begin{array}{l}23.64 \pm \\
0.76^{\mathrm{de}}\end{array}$ & $\begin{array}{c}242.32 \pm \\
3.10^{\mathrm{de}}\end{array}$ & $\begin{array}{c}24.61 \pm \\
0.56^{\mathrm{f}}\end{array}$ & $\begin{array}{l}9.78 \pm \\
0.31^{\mathrm{e}}\end{array}$ & $\begin{array}{l}34.56 \pm \\
0.59\end{array}$ & $\begin{array}{l}7.42 \pm \\
0.30 \text { ef }\end{array}$ \\
\hline $\begin{array}{c}\mathrm{Cd}(1.0 \mathrm{mM}) \\
+\mathrm{MP}\end{array}$ & $\begin{array}{c}22.88 \pm \\
0.20^{\mathrm{ef}}\end{array}$ & $\begin{array}{l}232.52 \pm \\
2.40^{\mathrm{f}}\end{array}$ & $\begin{array}{l}23.61 \pm \\
0.50 \mathrm{fg}\end{array}$ & $\begin{array}{l}9.05 \pm \\
0.31^{\mathrm{f}}\end{array}$ & $\begin{array}{l}32.29 \pm \\
1.16^{\mathrm{gh}}\end{array}$ & $\begin{array}{l}6.79 \pm \\
0.56\end{array}$ \\
\hline $\begin{array}{c}\mathrm{Cd}(1.5 \\
\mathrm{mM})+\mathrm{MO}\end{array}$ & $\begin{array}{l}23.08 \pm \\
0.25^{\text {ef }}\end{array}$ & $\begin{array}{l}234.62 \pm \\
4.71{ }^{\text {ef }}\end{array}$ & $\begin{array}{l}22.88 \pm \\
0.30^{\mathrm{gh}}\end{array}$ & $\begin{array}{l}8.89 \pm \\
0.35^{\mathrm{fg}}\end{array}$ & $\begin{array}{l}31.58 \pm \\
1.02^{\mathrm{h}}\end{array}$ & $0.81 \pm$ \\
\hline $\begin{array}{c}\text { Cd }(1.5 \mathrm{mM}) \\
+\mathrm{MP}\end{array}$ & $\begin{array}{l}22.31 \pm \\
0.955^{\mathrm{fg}}\end{array}$ & $\begin{array}{c}178.95 \pm \\
3.24^{\mathrm{g}}\end{array}$ & $\begin{array}{c}20.35 \pm \\
0.51^{\mathrm{i}}\end{array}$ & $\begin{array}{l}8.11 \pm \\
0.26^{h}\end{array}$ & $\begin{array}{c}26.41 \pm \\
0.51^{\mathrm{j}}\end{array}$ & $\begin{array}{l}6.45 \pm \\
0.26^{\mathrm{g}}\end{array}$ \\
\hline $\mathbf{L S D}_{0.05}$ & 0.827 & 9.183 & 1.208 & 0.618 & 1.783 & 0.651 \\
\hline
\end{tabular}


Effect of MO or MP on wheat relative water content under $C d^{2+}$ stress

Cadmium stress significantly reduced the percentage of relative water content (RWC) in leaves of wheat plants at different applied concentrations ( 0.5 and 1.5 $\mathrm{mM}$ ) as compared to untreated control and other treated plants. The treatment of soil with Moringa seed powder separately, increased the percentage of relative water content (\%RWC) in leaves of wheat plants in comparison with the untreated control plants. The soil application with the combined treatments $\mathrm{MO}+0.5 \mathrm{mM} \mathrm{Cd}$ and $\mathrm{MO}+1.5 \mathrm{mM} \mathrm{Cd}$ or MP + $0.5 \mathrm{mM} \mathrm{Cd}$ and $\mathrm{MP}+1.5 \mathrm{mM}$ $\mathrm{Cd}$ induced the high significant increases in \%RWC compared to their corresponding controls. The application of MO seed powder reveals the most increase in the percentage of RWC compared to MP (either alone or in combination with $\mathrm{Cd}^{2+}$ stress) (Table 4).

TABLE 4. Effect of soil application of defatted Moringa oleifera (MO) and Moringa peregrina (MP) seeds on percentage of relative water content (\% RWC) of leaves of 35 day old seedlings of wheat (Triticum aestivum) grown under Cd- acetate stress. Each value is the mean of three variables.

\begin{tabular}{|l|c|}
\hline \multicolumn{1}{|c|}{ Parameters } & \% of RWC \\
\hline Control & $81.5 \pm 3.04^{\mathrm{b}}$ \\
\hline MO & $93.7 \pm 3.51^{\mathrm{a}}$ \\
\hline MP & $90.27 \pm 3.64^{\mathrm{a}}$ \\
\hline Cd $(\mathbf{0 . 5} \mathbf{~ m M})$ & $68.47 \pm 5.39^{\mathrm{de}}$ \\
\hline Cd $(\mathbf{1 . 5} \mathbf{~ m M})$ & $44.7 \pm 3.85^{\mathrm{f}}$ \\
\hline Cd $(\mathbf{0 . 5} \mathbf{~ m M})+$ MO & $79.05 \pm 2.16^{\mathrm{bc}}$ \\
\hline Cd $(\mathbf{0 . 5} \mathbf{~ m M})+$ MP & $73.53 \pm 2.34^{\mathrm{cd}}$ \\
\hline Cd $(\mathbf{1 . 5} \mathbf{~ m M})+$ MO & $74.53 \pm 3.82^{\mathrm{cd}}$ \\
\hline Cd $(\mathbf{1 . 5} \mathbf{~ m M})+$ MP & $64.8 \pm 1.7^{\mathrm{e}}$ \\
\hline LSD $\mathbf{0 . 0 5}$ & 2.81 \\
\hline
\end{tabular}

Effect of MO or MP seed powder on wheat photosynthetic pigments under $\mathrm{Cd}^{2+}$ stress

Wheat plants subjected to Cd stress show high significant decreases in leaf contents of chlorophylls ( $\mathrm{a} \& \mathrm{~b}$ ) and carotenoids below those of untreated controls. The soil application with MO or MP improved the above parameters above those of untreated controls. The toxic effect of $\mathrm{Cd}^{2+}$ stress was significantly mitigated in case of combination between MO or MP and $\mathrm{Cd}$ combination, where the MO and MP can improve the photosynthetic pigments compared with their corresponding Cd-treated controls (Fig. 1).

Egypt. J. Bot., Vol. 56, No. 3 (2016) 
(A) Chlorophyll a

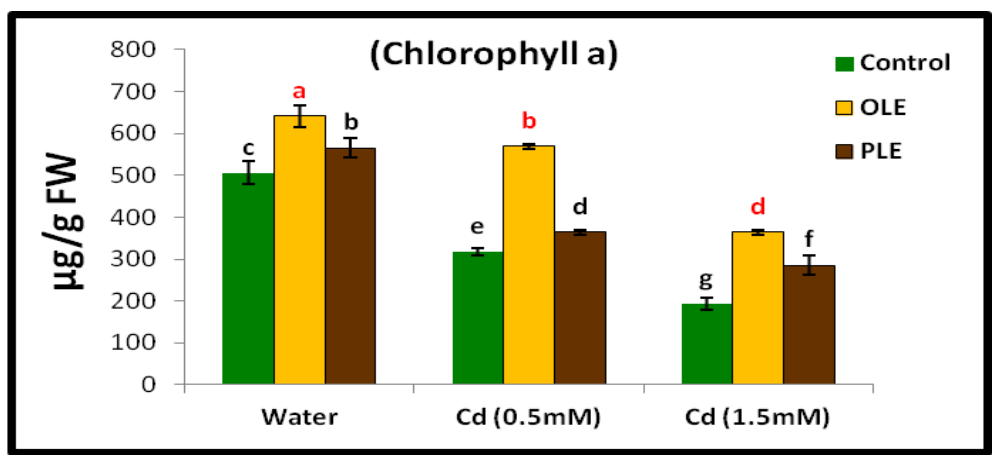

(B) Chlorophyll b

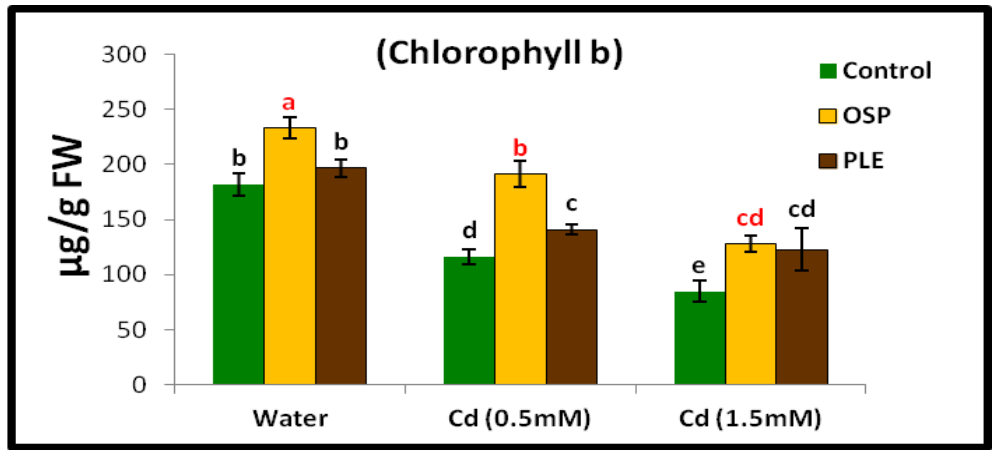

(C) Carotenoids

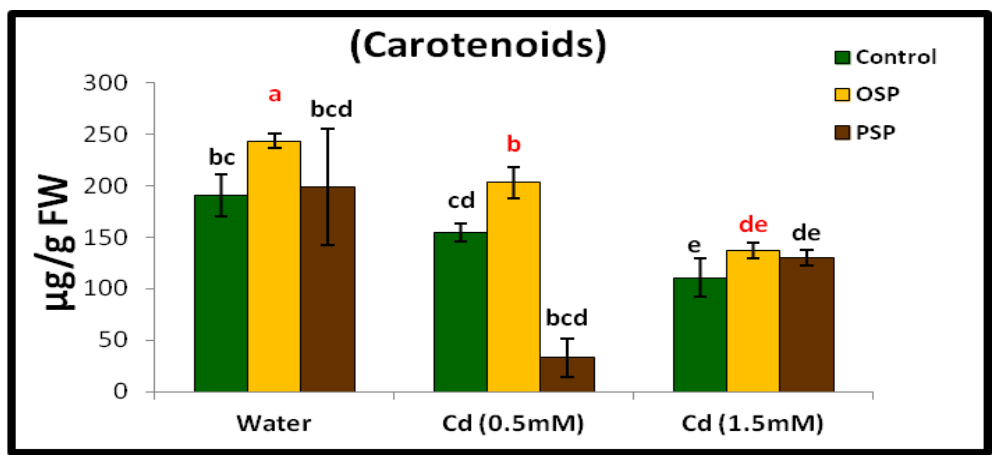

Fig. 1. Effect of soil application of defatted Moringa oleifera (MO) and Moringa peregrina (MP) seeds powder on photosynthetic pigments content of leaves ( $\mu \mathrm{g} \mathrm{g}^{-1} \mathrm{FW}$ ) of 30 day old seedlings of wheat (Triticum aestivum) grown under Cd- stress. 
Effect of MO or MP on wheat content of $\mathrm{Cd}^{2+}$ under $\mathrm{Cd}^{2+}$ stress

The stress generated by $\mathrm{Cd}^{2+}$ led to high accumulation of $\mathrm{Cd}^{2+}$ content in the roots and shoots of wheat plants. Plant roots were shown to be more affected than shoots. The toxic effect of cadmium stress was improved by applying the MO or MP to the soil-cultivated wheat plants. Non-significant changes in $\mathrm{Cd}^{2+}$ contents were observed in roots and shoots of wheat plants- treated with MO or MP- as compared with those of their corresponding controls (Fig. 2).

(A) $\mathrm{Cd}^{2+}$ content in Roots

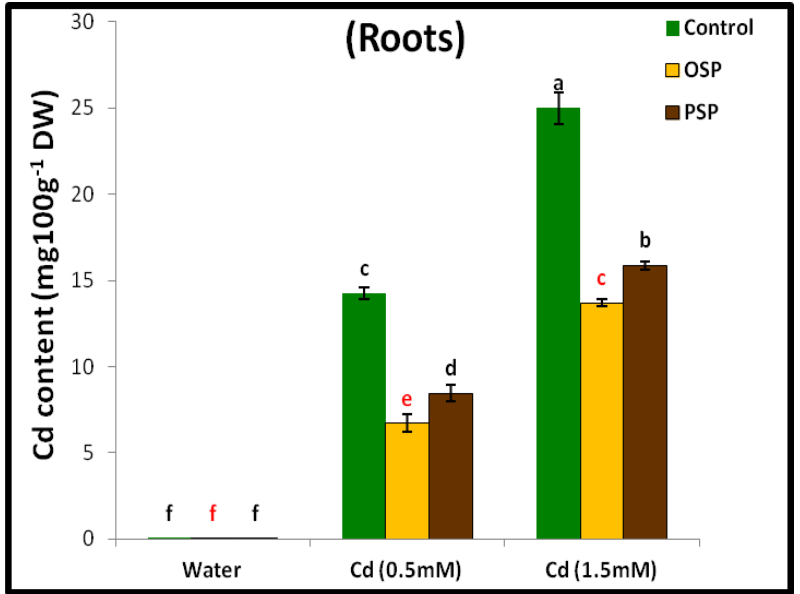

(B) $\mathrm{Cd}^{2+}$ content in Shoots

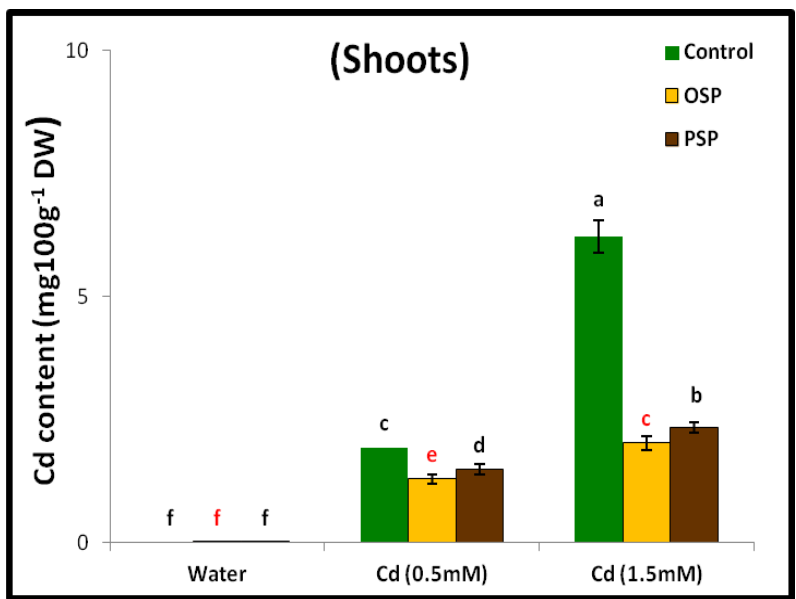

Fig. 2. Effect of soil treatment of defatted Moringa oleifera seed powder (MO) and Moringa peregrina seed powder (MP) on $\mathrm{Cd}^{2+}$ content of shoots and roots of 35 day old seedlings of wheat (Triticum aestivum) grown under Cd-stress. 
Effect of MO or MP on protein banding pattern of wheat plant under $\mathrm{Cd}^{2+}$ stress

Cadmium induced changes in protein patterns of wheat plant Table 5 and plate 2 , reveal that 15 protein bands of molecular weights: 182.24, 105.6, 100.6, 89.0, 63.41, 58.5, 55.0, 47.8, 42.2, 36.0, 32.73, 27.1, 25.0, 21.43 and $15.87 \mathrm{KDa}$ were expressed in the leaves of untreated control wheat plant. The band of MW 182.24 $\mathrm{KDa}$ is a unique band while the others were polymorphic proteins. Treatment with $0.5 \mathrm{mM} \mathrm{Cd}$ induced the expression of two proteins of molecular weights 261.38 and $170.92 \mathrm{KDa}$, while $1.5 \mathrm{mM} \mathrm{Cd}$ induced the expression of 3 proteins of molecular weights 114.0, 97.0, 74.14 KDa in the leaves of treated wheat plants. In addition, the 2 concentrations of $\mathrm{Cd}$ induced the expression of 5 proteins, their molecular weights are 217.77, 135.4, 51.6, 45.0 and $38.2 \mathrm{KDa}$ in the leaves of $\mathrm{Cd}$ treated wheat plants. The combined effect of MO defatted seed powder or MP defatted seed powder with $0.5 \mathrm{mM}$ or $1.5 \mathrm{mM} \mathrm{Cd}$ on protein banding pattern of wheat leaves indicated the expression of 11 proteins, their molecular weights are $261.38,217.77,177.38,135.4,114.0,97.0,74.14,51.6$, 38.2, 24.0 and 13.5 KDa. Of the above eleven proteins, one might be expressed due MO or MP powder (177.38 KDa) and the others (13.5 and $24 \mathrm{KDa})$ were induced by MP seed powder.

\section{Discussion}

The industrial activities greatly polluted the environment and deteriorate the ecosystems due to the presence of contaminants in their effluent (Lenardão et al. 2003), from these activities contaminant toxic heavy metals that cause damage to ecosystems and human health due to their incorporation into the food chain (Bazrafshan et al., 2013). Cadmium is considered as the most poisonous heavy metals even at low doses (Yurtsever and Sengil 2009), the presence of excessive amount of $\mathrm{Cd}$ in soil causes many toxic symptoms in plants such as chlorosis, growth inhibition, browning of root tips and finally death (Guo et al., 2008). For the removal of heavy metals, there are many synthetic coagulants such as activated carbon which was used widely in the treatment of effluents (Wan Ngah and Hanafiah, 2008), also synthetic coagulants of aluminum (alum lime, aluminum sulphate, and polyaluminum silico sulphate), ferric salts (iron hydroxide and iron chloride) and soda ash are also widely used processes (Bazrafshan et al., 2013). But their use in large scale becomes costly and in some cases has limited application and also serious to the environment (Ahluwalia and Goyal, 2007). Thus, the search for an alternative, low cost, highly efficient adsorbents must be needed and widely used in the developing world (Choong $e t$ al., 2007). The alternative materials such as waste agricultural and agroindustrial byproducts, that are produced in large quantities, relatively inexpensive and many of these materials have ability in sorption of metal ions and hence are known as biosorbents (Santos et al. 2011) and also have advantages such as biodegradability, low sludge production and fewer risks to health and environment (Mahdavi et al., 2012). 
TABLE 5. protein banding pattern of leaves of wheat plant (Triticum aestivum) treated with cadmium alone or in combination with defatted seed powder of Moringa oleifera (MO) or Moringa peregrina (MP), (Mwt \& amount).

\begin{tabular}{|c|c|c|c|c|c|c|c|c|c|c|}
\hline $\begin{array}{l}\text { MW } \\
\text { KDa }\end{array}$ & H2O & $\begin{array}{c}0.5 \mathrm{mM} \\
\mathrm{Cd}\end{array}$ & $\begin{array}{c}1.5 \mathrm{mM} \\
\mathrm{Cd}\end{array}$ & MO & MP & $\begin{array}{l}\mathrm{MO+0.5} \\
\mathrm{mM} \mathrm{Cd}\end{array}$ & \begin{tabular}{|l|}
$\mathrm{MP}+0.5$ \\
$\mathrm{mM}$ Cd
\end{tabular} & $\begin{array}{l}\text { MO+1.5 } \\
\text { mM Cd }\end{array}$ & \begin{tabular}{|l|}
$\mathrm{MP}+1.5$ \\
$\mathrm{mM}$ Cd
\end{tabular} & $\begin{array}{l}\text { MW } \\
\text { KDa }\end{array}$ \\
\hline 261.38 & - & 3.66 & - & - & - & - & 3.35 & 2.83 & 3.5 & \\
\hline 251.69 & - & - & - & - & - & - & - & - & - & \\
\hline 225.85 & - & - & - & 2.64 & 3.08 & - & - & - & - & \\
\hline 217.77 & - & 3.82 & 4.41 & - & - & 2.69 & 2.69 & 3.52 & 6.4 & \\
\hline 206.46 & - & - & - & - & - & - & - & - & - & - \\
\hline 200.00 & - & - & - & - & - & - & - & - & - & - \\
\hline 190.31 & - & - & - & 3.12 & 5.09 & - & - & - & - & - \\
\hline 182.24 & 3.78 & - & - & - & - & - & - & - & - & - \\
\hline 177.38 & - & - & - & - & - & 3.24 & 2.95 & 3.90 & 4.15 & \\
\hline 170.92 & - & 4.08 & - & - & - & - & - & - & - & - \\
\hline 145.1 & - & - & - & - & 3.6 & -- & - & - & - & - \\
\hline 135.4 & - & 4.39 & 4.21 & - & - & 3.08 & 3.0 & 3.13 & 2.9 & - \\
\hline 116.0 & - & - & - & 2.73 & 6.77 & - & - & - & - & 116. \\
\hline 114.0 & - & - & 3.77 & - & - & 2.81 & 3.65 & 3.0 & 3.3 & \\
\hline 105.6 & 3.54 & 4.89 & 3.87 & 3.1 & 3.52 & 2.9 & 14.7 & - & 5.62 & \\
\hline 100.6 & 2.58 & - & - & 2.37 & 3.26 & - & - & 2.88 & - & \\
\hline 97.0 & - & - & 3.17 & - & - & 3.3 & 2.8 & - & - & 97.0 \\
\hline 89.0 & 4.15 & 6.47 & 2.9 & 3.33 & 3.31 & 3.81 & 3.09 & 2.78 & - & - \\
\hline 74.14 & - & - & 3.9 & - & - & 3.43 & 2.21 & 2.28 & 3.78 & \\
\hline 68.3 & - & - & - & 4.41 & 2.79 & - & - & - & - & - \\
\hline 66.0 & - & - & - & - & - & - & - & - & - & 66.0 \\
\hline 63.41 & 4.35 & 4.64 & - & 3.91 & 3.16 & 3.46 & 3.12 & 3.46 & 3.57 & \\
\hline 58.5 & 3.6 & 4.42 & 3.95 & - & 5.32 & 4.0 & 3.51 & 4.62 & 3.29 & \\
\hline 55 & 3.66 & - & - & 3.42 & 4.5 & - & 3.26 & - & 3.59 & 55 \\
\hline 51.6 & - & 4.8 & 4.04 & - & - & 4.34 & 3.32 & 5.12 & 7.25 & \\
\hline 47.8 & 5.26 & - & - & 4.28 & - & 3.66 & - & - & - & - \\
\hline 45.0 & - & 4.9 & 3.42 & - & 4.29 & 3.72 & - & - & 4.0 & 45.0 \\
\hline 42.2 & 4.45 & - & 4.17 & 4.0 & 4.5 & - & - & 6.14 & 3.77 & \\
\hline 38.2 & - & 5.54 & 4.24 & - & - & 3.86 & 4.53 & - & - & \\
\hline 36.0 & 5.82 & - & - & - & - & 7.83 & - & - & - & 36.0 \\
\hline 32.73 & 10.8 & 9.62 & 10.1 & 10.3 & 13.6 & - & 10.8 & 12.9 & 10.3 & \\
\hline 29 & - & - & - & 3.08 & - & 4.1 & - & 3.53 & 4.33 & 29 \\
\hline 27.1 & 4.13 & 4.34 & 3.87 & 4.29 & - & - & 3.99 & - & - & \\
\hline 25.0 & 4.42 & 4.28 & 33.85 & - & 5.12 & - & 5.25 & - & 4.2 & - \\
\hline 24 & - & - & - & - & - & 9.08 & - & 5.91 & - & 24 \\
\hline 21.43 & 5.42 & 4.64 & 31.0 & 8.65 & 6.53 & - & 4.21 & - & 4.86 & - \\
\hline 15.87 & 4.78 & 4.24 & 5.74 & - & - & 4.26 & 3.83 & 5.27 & 4.64 & \\
\hline 14.2 & - & - & - & - & 4.45 & - & - & - & - & 14.2 \\
\hline 13.5 & - & - & - & - & - & 4.14 & - & - & - & \\
\hline $\begin{array}{l}\text { No. of } \\
\text { bands }\end{array}$ & 15 & 16 & 17 & 16 & 17 & 19 & 19 & 14 & 18 & \\
\hline
\end{tabular}

Egypt. J. Bot., Vol. 56, No. 3 (2016) 


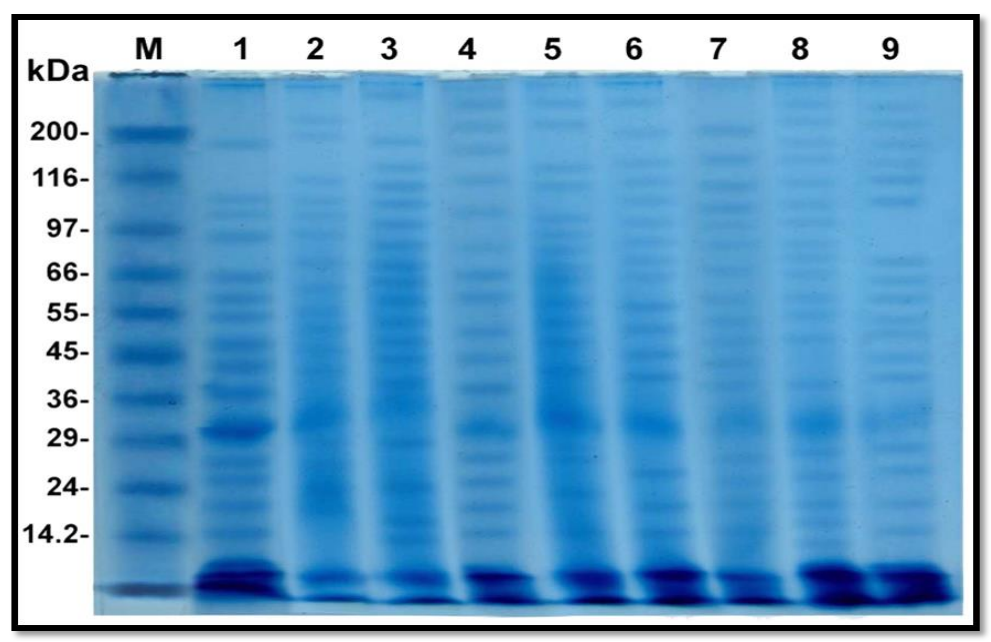

Plate 2. electrograph of soluble protein pattern by one-dimension SDS-PAGE showing the changes of protein bands in response to different concentrations of cadmium either alone or in combination with defatted seed powder of Moringa oleifera (MO) or Moringa peregrina (MP)

Lan(1): $\mathrm{H}_{2} \mathrm{O}$

$\operatorname{Lan}(3): \mathrm{Cd}(1.5 \mathrm{mM})$

$\operatorname{Lan}(2): \mathrm{Cd}(0.5 \mathrm{mM})$

Lan(5): MP

$\operatorname{Lan}(7): \mathrm{MP}+\mathrm{Cd}(0.5 \mathrm{mM})$

$\operatorname{Lan}(9): \mathrm{MP}+\mathrm{Cd}(1.5 \mathrm{mM})$

$\operatorname{Lan}(4): \mathrm{MO}$

$\operatorname{Lan}(6): \mathrm{MO}+\mathrm{Cd}(0.5 \mathrm{mM})$

$\operatorname{Lan}(8): \mathrm{MO}+\mathrm{Cd}(1.5 \mathrm{mM})$

In this study, the byproduct (seed cake originated after the oil extraction of seeds) coms from the seeds of Moringa species (Moringa oleifera and Moringa peregrina) which contained 6 protein bands, their molecular weights are 64.5, 51.4, 41.2, 38.3, 27.9 and 18.9 KDa. These proteins may have coagulant properties with the ability to bind the ions of heavy metals to form complexes (Bazrafshan $e t$ al., 2013). From our results presented in (Fig. 2) the application of MO and MP seed powders separately or in combination with Cd- treatments has the ability to coagulate the $\mathrm{Cd}^{2+}$ in the soil, the mechanisms by which the seed powder of both species can coagulate the cadmium in the soil must be understood. In this respect, Meneghel et al. (2013), suggested that the process of adsorption and coagulation of $\mathrm{Cd}^{2+}$ is a result of electrostatic interactions and formation of complexes between the metal ions and the functional groups present in the adsorbent biomass. These groups $(\mathrm{O}-\mathrm{H}, \mathrm{N}-\mathrm{H}, \mathrm{C}-\mathrm{H}$, and $\mathrm{C}-\mathrm{O})$ present in carbohydrates, proteins, lipids, and lignin. Also, Yongabi et al. (2011), suggested that the active coagulant components is a protein materials. Okuda et al. (2001), reported that there are two active coagulant components were extracted from Moringa oleifera seeds one of them extracted by using salt solution (MOC-SC) (Agrawal et al., 2007) and the other extracted by distilled water (MOC-DW), both of them have the ability to coagulate wastes from turbid water. MWt of the former MOC-SC was about $3 \mathrm{KDa}$, while that of the later (MOC-DW) was about 12-14 KDa (water soluble- cationic 
polypeptide) (Santos et al., 2012). The coagulation mechanism of MOC-DW was reported by Ndabigengesere et al. (1995) which include adsorption and neutralization of charges or adsorption and bridging of destabilized particles where this polypeptide carry a net positive charges so it proposed to bind to negatively charged particles (silt, clay, bacteria, etc. suspended in a colloidal form), that make raw waters turbid. The previous results that the coagulation component was proteins have been reported by Agrawal et al. (2007), where they extracted and purified a high molecular mass protein with MWt about $66 \mathrm{KDa}$ on $15 \%$ SDSPAGE. Finally, Agrawal et al. (2007) suggested that the flocculation coagulation activity and antimicrobial activity of seeds come from MO plant is a cumulative effect of various active components. The purified active components if used together for water treatment can be more effective in clarifying the water than the individual active components.

It is clearly shown from Table 3 that Cd-treatment of wheat plant inhibited all the growth parameters (shoot length, shoot FW \& DW, root length and root FW \& DW) and this inhibition increased with increasing $\mathrm{Cd}$ concentration. The reduction of growth by $\mathrm{Cd}$ toxicity could be mainly due to the role of $\mathrm{Cd}$ on inhibition of chlorophyll synthesis (Padmaja et al., 1990) and photosynthetic rate as well as detrimental effects on chloroplast replication and cell division (Baryla et al., 2001). Inhibition of root growth in Cd-treated plants may be due to the reduced water uptake, also, the reduction in root growth may be due to reductions in both new cell formation and cell elongation of the root (Raziuddin et al., 2011). In the present investigation, Table 4 shows that $\mathrm{Cd}^{+2}$ adversely affect the percentage of RWC in Cd treated-wheat plants. It was found from our results that using Moringa seed cake in soil for wheat plants improved the growth of seedling if compared to Cd-treated and non- treated control plants. This was confirmed by our results (Table 1) and those of Emmanuel et al. (2011), who reported that MO seed cake has high content of phytohormones, macro, micronutrient and antioxidant compounds such as ascorbic acid, reduced glutathione and total phenol, so increased the mineral content of the soil, and hence improved the growth of the crop plants as compared to the control ones. The decrease in leaf conductance and relative water content could be due to a direct $\mathrm{Cd}^{+2}$-induced stomatal closure (Perfus-Barbeoch et al., 2002), through disturbance of hormonal balance that may reduce water transport and reduced \% RWC (Table 4).

Cadmium stress negatively affects the photosynthetic pigments (ch a, ch b and carotenoids) in stressed wheat plants (Fig. 1). This reduction in chlorophyll contents in Cd-treated plants may be due to inhibition of its biosynthesis (Padmaja et al., 1990). Cadmium may substitute $\mathrm{Mg}$ ion in the chlorophyll molecules and this will lead to chlorophyll destruction (Baryla et al., 2001). Also lowering the chlorophyll contents under Cd stress result from the activation of its enzymatic degradation by chlorophyllase ( Vassilev and Yordanov, 1997).

As shown in (Fig. 2), wheat roots had much higher $\mathrm{Cd}^{2+}$ concentration than shoots, this result was acceptable in cereal crops because these parts are not generally utilized as food or feed (Zhang et al., 2002).

Egypt. J. Bot., Vol. 56, No. 3 (2016) 
The effects of $\mathrm{Cd}^{2+}$ ions on protein expression revealed differential expression of various proteins (Kranner and Colville, 2011), five protein bands of molecular weights 217.77, 135.4, 51.6, 45.0 and 38.2 KDa were expressed in Cd-treated wheat plants. They may be Cd stress proteins (Table 5, Plate 2). During $\mathrm{Cd}$ stress, the activity of proteins can be affected by reactive oxygen species (Romero-Puertas et al., 2002). Where proteins can undergo oxidative modification through direct reaction with ROS, and also through interaction with the aldehyde products of lipid peroxidation (Sandalio et al., 2001), these products reacts with free amino groups of proteins leading to protein carbonylation which is the common oxidative protein modification in which the side-chains of amino acids are converted to aldehyde or keto groups, leading to inactivation of proteins and cross linking. On the other hand, Cd-stress can promote expression of stress-responsive genes and subsequently proteins, thereby increasing the levels of RNA and proteins (Maheshwari and Dubey, 2008). These proteins may bind $\mathrm{Cd}^{2+}$ forming phytochelatins and metallothioneins which have been sequestered in the vacuole. Application of the seed powder of both Moringa species in the soil of wheat plants can lead to the expression of 11 new protein bands in leaves. These protein bands having molecular weights of $261.38,217.77,177.38,135.4,114.0,97.0,74.14,51.6$, 38.2, 24.0 and $13.5 \mathrm{KDa}$, that may have the ability to chelate the $\mathrm{Cd}^{2+}$ ions, thus decreasing their content in roots and shoots of wheat plants (Table 5 and Plate 2). In our opinion the improvement in growth of wheat seedlings in pots treated with both Moringa species separately or in combination with $\mathrm{Cd}^{2+}$ concentrations may be related to the ability of seed cake to chelate $\mathrm{Cd}^{2+}$ from the Moringa- treated soil, thus the plants can grow in normal conditions and revealed normal growth. Generally, we reported that application of Moringa oleifera seed cake was more effective in removing $\mathrm{Cd}^{2+}$ ions from the soil than Moringa peregrina (Fig. 2). There is no information recorded concerning this study.

\section{Conclusion}

Moringa seed powder being a good coagulant for $\mathrm{Cd}^{2+}$ metals from the soil under stress condition. MSP can enhance the tolerance of wheat plants to heavy metal stress. Also improved the tolerance of wheat plant by increasing growth of wheat plant under stress-free development under stress-free condition and stress conditions via phytohormones, antioxidant compounds, macro and micronutrient-rich Moringa seeds.

\section{References}

Abd El-Baky, H.H. (2009) Enhancing antioxidant availability in grains of wheat plants grown under seawater-stress in response to microalgae extracts treatments. African $J$. Biochem. Resear., 3, 077-083.

Agami, R.A. and Mohamed, G.F. (2013) Exogenous treatment with indole-3-aceticacid and salicylic acid alleviates cadmium toxicity in wheat seedlings. Ecotoxicol. Environ. Saf., 94, 164-171. 
Agarwal, S. and Shaheen, R. (2007) Stimulation of antioxidant system and lipid peroxidation by abiotic stress in leaves of Momordica charantia. Brazilian J. Plant Physiol., 19, 149-161.

Ahluwalia, S.S. and Goyal, D. (2007) Microbial and plant derived biomass for removal of heavy metals from wastewater. Bioresource Technol., 98, 2243-2257.

Amin, H., Hamid M. R. A., Lada, S., and Anis, Z. (2008) "The adoption of mobile banking in Malaysia: the case of Bank Islam Malaysia Berhad (BIMB)”. I. J. Business Soci., 9, 43-53.

Babel, S. and Kurniawan, T.A. (2003) Low-cost adsorbents for heavy metals uptake from contaminated water: A review. J. Hazard. Mater., 97, 219-243.

Barakat, M.Z., Shehab, S.K., Darwish, N. and El-Zoheiry, E. (1973) A new titrimetric method for the determination of vitamin C. Anal Biochem., 53, 245-251.

Baryla, A., Carrier P., Franck F., Coulomb C., Sahut C. and Havaux M. (2001) Leaf chlorosis inoilseed rape plants (Brassica napus) grown on cadmium polluted soil: causes and consequences for photosynthesis and growth. Planta., 212, 696-709.

Bates, L.S., Waldeen, R.P. and Teare, I.D. (1973) Rapid determination of free proline for water stress studies. Plant Soil., 39, 205-207.

Bazrafshan, E., Faridi, H., Pour, M., Kord, F. and Mahvi, A.H. (2013) Removal of arsenic from aqueous environments using Moringa peregrina seed extract as a natural coagulant. Asian J. Chem., 25, 3557-3561.

Chapman, H.D. and Pratt, P.F. (1961) "Method of Analysis for Soil, Plants and Waters". University of California, Agricul. Sci., Berkeley p. 309.

Choong, S.Y., Chuah, T.G., Robiah, Y., Koay, F.L.G. and Azni, I. (2007) Arsenic toxicity, health hazards and removal techniques from water: an overview. Desalination., 217, 139-166.

Daniel, H.D. and George, C.M. (1972) Peach seed dormancy in relation to indogenous inhibitors and applied growth substances. J. Amer. Soc. Hort. Sci., 97, 651-654.

Daughaday, W.H., Lowry, O.H., Rosenbrough, N.J. and Fields, W.S. (1952) Determination of cerebrospinal fluid protein with the Folin phenol reagent. J. Lab Clin. Med., 4, 7663-665.

Emmanuel, S.A., Zaku, S.G., Adedirin, S.O., Tafida, M. and Thomas, S.A. (2011) Moringa oleifera seed-cake, alternative biodegradable and biocompatibility organic fertilizer for modern farming. Agric. Biol. J. N. Am., 2, 1289-1292.

Fardet, A., Rock, E. and Remesy, C. (2008) Is the in vitro antioxidant potential of wholegrain cereals and cereal products well reflected in vivo?. J. Cereal Sci., 48, 258-276.

Foidle, N., Makkar, H.P.S. and Becker, K. (2001) The potential of Moringa oleifera for agricultural and industrial uses. In: The Miracle Tree: "The Multipurpose Attributes of Moringa” Fugile, L (Ed.), “. CTA Publications Wageningen. The Netherlands, pp.45-76. 
Guo, J., Dai, X., Xu, W. and Ma, M. (2008) Over expressing GSHI and AsPCSI simultaneously increases the tolerance and accumulation of cadmium and arsenic in Arabidopsis thaliana. Chemosphere., 72, 1020-1026.

Hames, B.D. and Rickwood, D. eds. (1981) Gel Electrophoresis of Proteins. A practical approach. London: IRL press limited.

Hassanein, R.A. (1977) Effect of certain growth regulators on plant growth and development. Ph.D. Thesis, Ain Shamas Univ., Cairo, Egypt.

Himesh, A., Chandan, S. and Ashwani, K.S. (2007) Isolation of a $66 \mathrm{kDa}$ protein with coagulation activity from seeds of Moringa oleifera. Res. J. Agric. Bio. Sci., 3, 418-421.

Hissin, P.J. and Hilf, R. (1976) A fluorometric method for determination of oxidized and reduced glutathione in tissues. Anal Biochem., 74, 214-226.

Howladar, S.M. (2014) A novel Moringa oleifera leaf extract can mitigate the stress effects of salinity and cadmium in bean (Phaseolus vulgaris L.) plants. Ecotoxicol. Environ. Saf., 100, 69-75.

Jenkins, S.H. (1930) The determination of cellulose in straws. Biochem. J., 24, 1428-1432.

Kranner, I. and Colville, L. (2011) Metals and seeds: Biochemical and molecular implications and their significance for seed germination. Environ. Exp. Bot., 72, 93-105.

Kumari, V., Ettinger, U., Crawford, T., Zachariah, E. and Sharma, T. (2005) Inhibitory deficits in chronic schizophrenia: lack of association between prepulse inhibition and antisaccadic abnormalities. J. Psychiat. Res., 39, 227-240.

Lenardão E.J., Freitag R.A., Dabdoub M.J., Batista A.C.F. and Silveira C.C. (2003) Green chemistry - the 12 principles of green chemistry and it insertion in the teach and research activities. Química Nova., 26,123-129.

Mahdavi, S., Jalali, M. and Afkhami, A. (2012) Removal of heavy metals from aqueous solutions using $\mathrm{Fe} 3 \mathrm{O} 4, \mathrm{ZnO}$, and $\mathrm{CuO}$ nanoparticles. J. Nanopart. Res., 14, 846.

Maheshwari, R. and Dubey, R. (2008) Inhibition of ribonuclease and protease activities in germinating rice seeds exposed to nickel. Acta. Physiol. Plantarum., 30, 863-872.

Malkowski, A. and Piotrowska, M. (2006) Antioxidant and free radical scavenging activities of some medicinal plants from the Lamiaceae. Fitoterapia., 77, 346-353.

Meara, M.L. (1955) Fats and other lipids. In "Modern Methods of Plant Analysis" (Ed. By K. Paech and M. V. Tracey). Springer-Vverlag, Berlin, Vol. II, 317-402,

Meneghel, A.P., Gonçalves, Jr A.C., Rubio, F., Dragunski, D.C., Lindino, C.A. and Strey, L. (2013) Biosorption of cadmium from water using Moringa (Moringa oleifera Lam.) seeds. Water Air Soil Pollut., 224, 1383-1395.

Metzner, H., Rau, H. and Senger, H. (1965) Untersuchungen zur synchronisier barkeep ein zelner pigment. mango i mutanten von chlorella. Planta., 65, 186. 
Muller, P. and Hilgenberg, W. (1986) Isomers of zeatin and zeatin riboside in club root tissue: evidence for trans-zeatin biosynthesis by Plasmadiophora brassicae. Physiol. Plant., 66, 245-250.

Muting, D. and Kaiser, E. (1963) Spectrophotometric method of determining of alfa-amino$\mathrm{N}$ in biological material by means of the ninhydrin reaction. Hoppe-Seyler`s Zschr Physiol. Chem., 332, 276-289.

Nand, V., Maata, M., Koshy, K. and Sotheeswaran S. (2012) Water purification using Moringa oleifera and other locally available seeds in Fiji for heavy metal removal. I. J. Applied Sci. Tech., 2, 125-129.

Nanji, D.R. and Norman, A.G. (1928) Studies on pectin. II. The individual pectic substances in nature. Biochem. J., 22, 596-604.

Ndabigengesere, A., Narasiah, K.S. and Talbot, B.G. (1995) Active agents and mechanism of coagulation of turbid waters using Moringa oleifera. Water Res., 29, 703-710.

Okuda, T., Baes, A.U., Nishijima W. and Okada M. (2001a) Isolation and characterization of coagulant extracted from Moringa oleifera seed by salt solution. Water Res., 35, 405-410

Okuda, T., Baes, A.U., Nishijima, W. and Okada, M. (2001b) Coagulation mechanism of salt solution-extracted active component in Moringa oleifera seeds. Water Res., 35, 830-834.

Padmaja, K., Prasad, D.D. K. and Prasad, A.R.K. (1990) Inhibition of chlorophyll synthesis in Phaseolus vulgaris seedlings by cadmium acetate. Photosynth., 24, 399-405.

Pagnanelli, F., Mainelli, S., Veglio, F. and Toro, L. (2003) Heavy metal removal by olive pomace: biosorbent characterization and equilibrium modeling. Chem. Eng. Sci., 58, 4709-4717.

Perfus-Barbeoch, L., Leonhardt, N., Vavasseur, A., and Forestier, C. (2002) Heavy metal toxicity: cadmium permeates through calcium channels and disturbs the plant water status. Plant J., 32, , 539-548.

Prud'homme, M.P., Gonzalez, B., Billard J.P. and Boucaud, J. (1992) Carbohydrate content, fructan and sucrose enzyme activities in roots, stubble and leaves of ryegrass (Lolium perenne L.) as affected by source/sink modification after cutting. J. plant. Physiol., 140, 282-291.

Ranganna, S. (1977) "Manual for Analysis of Fruit and Vegetable Products". Tata McGraw Hill Publ. Co Ltd., New Delhi. P. 634.

Raziuddin, F., Ghulam, H., Akmal, M., Shah, S.S., Mohammad, F., Shafi, M., Bakht, J. and Zhou, W. (2011) Effects of cadmium and salinity on growth and photosynthesis parameters of brassica species. Pak. J. Bot.., 43, 333-340.

Rezzoug, S.A., Maache-Rezzoug, Z., Sannier, F. and Allaf, K. (2008) A thermo mechanical preprocessing for pectin isolation from orange peel. Optimisation by response surface methodology. I. J. Food Eng., 4, Article 10. 
Romero-Puertas, M.C., Palma, J.M., Gomez, M., Del Rio, L.A. and Sandalio, L.M. (2002) Cadmium causes the oxidative modification of proteins in pea plants. Plant Cell Environ., 25, 677-686.

Saltanapour, P.N. (1985) Use of ammonium bicarbonate DPTA soil test to evaluated elemental availability and toxicity. Soil. Sci. Plant Anal., 16, 333-338.

Sandalio, L.M., Dalurzo, H.C., Gómez, M., Romero-Puertas, M.C. and Del Río, L.A. (2001) Cadmium induced changes in the growth and oxidative metabolism of pea plants. J. Exp. Bot., 52, 2115-2126.

Santos, A.F.S., Argolo, A.C.C., Paiva, P.M.G. and Coelho, L.C.B.B. (2012) Antioxidant activity of Moringa oleifera tissue extracts. Phytother. Res., 26, 1366-1370.

Santos, M.E., Athanasiadis, A., Leitão, A.B., Dupasquier, L., and Sucena E. (2011) Alternative splicing and gene duplication in the evolution of the FoxP gene subfamily. Mol. Biol. Evol., 28, 237-247.

Shindy, W.W. and Smith O. (1975) Identification of plant hormones from cotton ovules. Plant Physiol., 55, 550-554.

Thayermanavan, V. and Sadasivam, S. (1984) "Qual Plant Foods Hum Nutr. Quoted from Biochemical Methods". Sadasivam, S. and A. Manickam, (Eds) $2^{\text {nd }}$ ed., 11-12. New ag. inter. Limit. Publ. New Delhi, India. 34, 253-257.

Vassilev, A. and Yordanov, I. (1997) Reductive analysis of factors limiting growth of cadmium-treated plants: a review. Bulg. J. Plant Physiol., 23, 114-133.

Wan Ngah, W.S. and Hanafiah, M.A K.M. (2008) Biosorption of copper ions from dilute aqueous solutions on base treated rubber (Hevea brasiliensis) leaves powder: kinetics, isotherm, and biosorption mechanisms. J. Environ. Sci., 20, 1168-1176.

Wasfy, W., Shindy, L.R. and Orrin E.S. (1974) Identification of plant hormones from cotton ovules. Plant Physiol., 55, 550-560.

Yemm, E.W. and Willis, A.J. (1954) The estimation of carbohydrates in plant extracts by anthrone. Biochem. J., 57, 508-514.

Yongabi, K.A., Lewis, D.M. and Harris, P.L. (2011) A Moringa oleifera disinfectant-sand filter integration: a review of an alternative sustainable technology for household water treatment. J. Environ. Sci. Eng., 5, 1100-1108.

Yurtsever, M. and Sengil, I. A. (2009) Biosorption of $\mathrm{Pb}$ (II) ions by modified quebracho tannin resin. J. Hazard. Mater., 163, 58-64.

Zhang, G., Fukami, M. and Sekimoto H. (2002) Influence of cadmium on mineral concentrations and yield components in wheat genotypes differing in Cd tolerance at seedling stage. Field Crop Res., 77, 93-98.

(Recrived 27/12/2015

accepted $7 / 1 / 2016$

Egypt. J. Bot., Vol. 56, No. 3 (2016) 


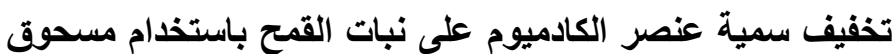 بذور البان (اللبان) أوليفيرا و بريجرينا منزوعة الدان الدهون كمرسبات

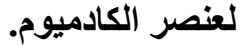

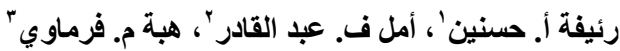

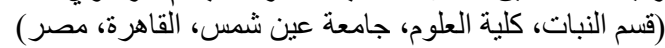

يتضمن هذا البحث دراسة الخصائص الغير منوقعة لنباتي، البان (اللبان) أوليفيرا

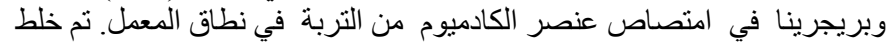

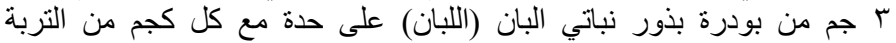

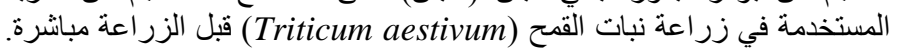

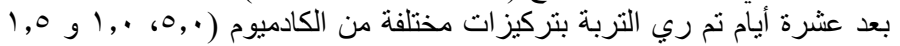

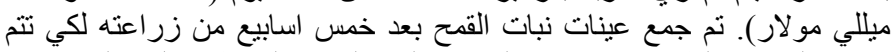

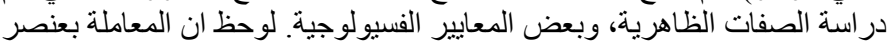

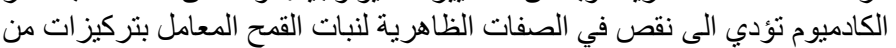

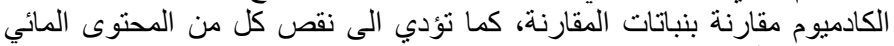

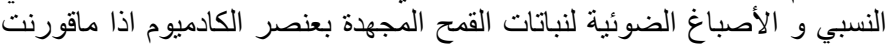

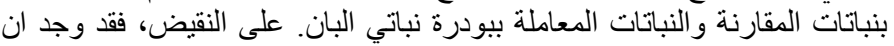

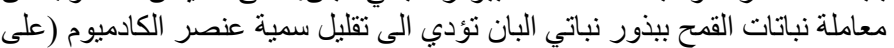

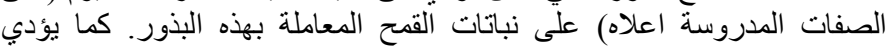

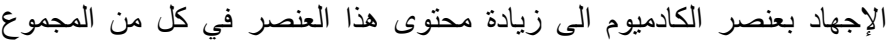

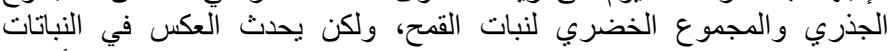

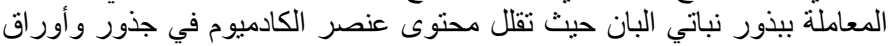

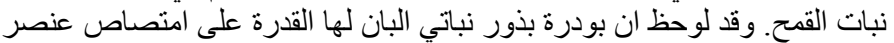

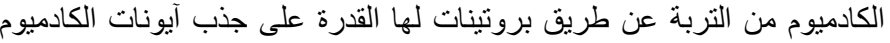

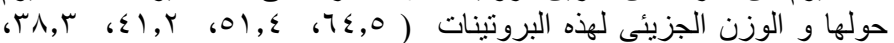

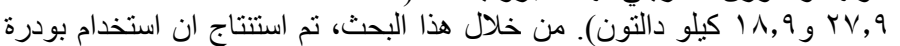

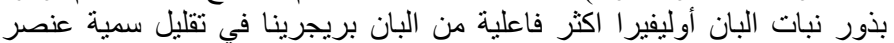

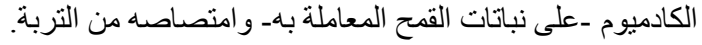

